\title{
Cardiac Surgery can be performed safely in patients with recent COVID-19 infection
}

\author{
Ana Lopez-Marco ${ }^{1}$, Martin Yates ${ }^{1}$, Cristina Suarez ${ }^{1}$, Azhar Hussain ${ }^{1}$, Damian Balmforth ${ }^{1}$, \\ Robert Serafino Wani ${ }^{1}$, Satya Das ${ }^{1}$, and Aung Oo ${ }^{1}$ \\ ${ }^{1}$ Saint Bartholomew's Hospital
}

August 4, 2020

\begin{abstract}
Surgery in patients diagnosed with COVID-19 infection carries significant mortality and morbidity but the appropriate waiting period before surgical intervention after recovering from COVID-19 is not known. We analysed the outcomes of patients who underwent cardiac surgery after having been diagnosed of COVID-19 on pre-operative screening between March and July 2020. Depending on the clinical urgency we delayed surgery until negative testing and/or radiological clearance or postponed the operation where possible. As a result of waiting until COVID-19 resolution, all of our patients survived surgery without complications.
\end{abstract}

\section{INTRODUCTION}

Reports describe high mortality and prolonged mechanical ventilation in surgical patients who diagnosed with COVID-19 in the peri-operative period [1-2]. In our own experience, developing COVID-19 in the immediate postoperative period following cardiac surgery carried a mortality up to $44 \%$ [3], mostly due to a combination of respiratory and renal failure likely exacerbated by the inflammatory effects of cardiopulmonary bypass.

Depending on the cardiac diagnosis, there might be an option to treat the patients medically, with less invasive procedures (i.e. PCI, TAVI or endovascular procedures) or to defer surgery until there is negative conversion of COVID-19 status, not knowing the optimum time from infection to cardiac surgery.

We analysed the outcomes of cardiac surgery in patients who underwent cardiac surgery after recovering from COVID-19.

\section{$M E T H O D S$}

Analysis of all patients undergoing cardiac surgery in our centre from March to July 2020, with focus on those diagnosed pre-operatively with COVID-19 (either a positive nasopharyngeal swab or by changes in the lung parenchyma on CT scan) and underwent subsequent surgery.

Our COVID-19 screening protocol consists of two consecutive nasopharyngeal swabs for polymerase chain reaction for ribonucleic acid (PCR-RNA) analysis by The Cobas SARS-CoV-2 (targeting virus Orf and E genes and is declared positive if either target was detected; it also reports the cycle threshold (Ct value) or the number of cycles of amplification before the PCR product is detected as positive), a non-contrast CT chest, lymphocyte count and Lactate Dehydrogenase (LDH) levels [4].

Individual patient's consent was waived by the Ethics Institutional Board since there was no patient identifiable data.

RESULTS 
During the study period a total of 375 patients underwent cardiac surgery in our institution.

Ten patients were diagnosed with COVID-19 in the preoperative screening and subsequently underwent surgery: 4 patients by a positive nasopharyngeal swab, 3 by CT changes in the lung parenchyma and 3 by a combination.

Male sex predominated $(80 \%)$ and mean age was $65.8(45-76)$ years. Cardiac diagnosis included: acute coronary syndrome $(n=5)$, acute aortic syndrome $(n=1)$, decompensated mitral regurgitation $(n=1)$, symptomatic severe aortic stenosis $(n=1)$, infective endocarditis $(n=1)$ and infected aortic graft $(n=1)$. (Table 1)

All the patients were discussed at MDTs with input from virologist/infection specialist. In all cases it was agreed that the optimal treatment was surgery without possibility for a less invasive approach.

Four patients were discharged home with medical therapy and readmitted for elective surgery. Mean delay to surgery was $67(50-84)$ days.

Six patients required urgent treatment during the same admission. Mean delay to surgery was $14.7(4-31)$ days. They were kept in isolation in a specialised cardiac unit and the screening was repeated every 48 hours until negative tests were obtained and/or the infiltrates disappeared on CXR.

None of the patients developed pyrexia while waiting for the operation and only one patient developed dyspnoea, probably due to acute heart failure.

Mean Euroscore was $3.3(1.09-7.93)$. Surgical procedures were: CABG $(n=4), C A B G+$ mitral replacement $(\mathrm{n}=1)$, mitral repair $(\mathrm{n}=1)$, AVR $(\mathrm{n}=2)$, aortic replacement $(\mathrm{n}=2)$. Mean bypass and cross clamp time was $122.4(67-305)$ and $82.8(36-158)$ minutes respectively. All surgeries were conducted with PPE precautions.

None of the patients developed respiratory complications in the postoperative period and were extubated uneventfully in the first two days. Mechanical ventilation times and length of postoperative stay were not prolonged. Postoperative swabs were negative for all patients.

All patients survived to hospital discharge. (Table 2).

\section{DISCUSSION}

Developing COVID-19 during the immediate postoperative period, regardless of the nature of surgery, carries a high mortality and morbidity related to respiratory complications [2-4].

In emergencies there is no option to wait for the swab results, hence the surgical indication outweighs the risk of COVID-19. However, in urgent cases, with margin to wait for the screening results we encountered a proportion of patients who were COVID-19 positive with mild or no symptoms.

The ideal convalescence period after having tested positive for COVID-19 is unknown, especially if no symptoms or abnormalities in the chest imaging. We believe it is important to manage each case individually, and when time permitting, to wait until negative for COVID-19 testing or drastically reduced viral load and resolution of the radiological infiltrates (if any).

Accuracy of the COVID-19 diagnostic tests is still suboptimal, with a high percentage of false negatives. Furthermore, a positive test does not necessarily indicate infectious virus particles in a patient with resolving infection. The $\mathrm{Ct}$ value can be seen as a pseudo-measure of the viral load (the lower the $\mathrm{Ct}$ value, the higher the viral concentration) and patients with COVID-19 with Ct above 24-26 could be considered non-contagious [5].

In our series, all patients who required urgent surgery had Ct values above that threshold and were probably not infectious but delaying surgery also allowed resolution of the systemic inflammatory reaction and thus did not see any postoperative complications. 
It might not be necessary to wait until total resolution of radiological changes or a negative PCR result but further studies on a larger volume of patients are needed to confirm this.

\section{CONCLUSIONS}

Postponing cardiac surgery in selected patients with confirmed COVID-19 was safe and enabled surgery to be performed with favourable outcomes in patients with low viral load and radiological resolution of lung infiltrates.

\section{TABLES}

\begin{tabular}{|c|c|c|c|c|c|c|c|}
\hline Patient & Sex & Age & Diagnosis & $\begin{array}{l}\text { Modality } \\
\text { of } \\
\text { COVID-19 } \\
\text { diagnosis }\end{array}$ & $\begin{array}{l}\text { Delay to } \\
\text { surgery } \\
\text { (days) }\end{array}$ & Surgery & $\begin{array}{l}\text { EuroScore } \\
\text { II }\end{array}$ \\
\hline 1 & M & 68 & $\begin{array}{l}\text { Infective } \\
\text { endocarditis }\end{array}$ & Swab & 31 & $\begin{array}{l}\text { Aortic } \\
\text { valve } \\
\text { replacement }\end{array}$ & 1.59 \\
\hline 2 & M & 61 & STEMI & $\begin{array}{l}\text { Swab }+ \\
\text { CT chest }\end{array}$ & 16 & CABG & 1.09 \\
\hline 3 & M & 59 & $\begin{array}{l}\text { Expanding } \\
\text { DTA } \\
\text { aneurysm }\end{array}$ & Swab & 5 & $\begin{array}{l}\text { DTA } \\
\text { replacement }\end{array}$ & 3.91 \\
\hline 4 & $\mathrm{M}$ & 45 & $\begin{array}{l}\text { Infected } \\
\text { aortic } \\
\text { graft }\end{array}$ & $\begin{array}{l}\text { Swab + } \\
\text { CT chest }\end{array}$ & 18 & $\begin{array}{l}\text { Ascending } \\
\text { aorta } \\
\text { replacement }\end{array}$ & 7.93 \\
\hline 5 & $\mathrm{M}$ & 71 & $\begin{array}{l}\text { Non } \\
\text { STEMI }\end{array}$ & Swab & 71 & CABG & 1.09 \\
\hline 6 & $\mathrm{M}$ & 75 & $\begin{array}{l}\text { Non } \\
\text { STEMI + } \\
\text { pulmonary } \\
\text { oedema }\end{array}$ & CT chest & 9 & $\begin{array}{l}\text { CABG + } \\
\text { Mitral } \\
\text { valve } \\
\text { replacement }\end{array}$ & 7.15 \\
\hline 7 & $\mathrm{~F}$ & 76 & $\begin{array}{l}\text { Severe } \\
\text { mitral } \\
\text { regurgitation }\end{array}$ & CT chest & 63 & $\begin{array}{l}\text { Mitral } \\
\text { repair }\end{array}$ & 2.42 \\
\hline 8 & $\mathrm{~F}$ & 69 & $\begin{array}{l}\text { Severe } \\
\text { aortic } \\
\text { stenosis }\end{array}$ & CT chest & 50 & $\begin{array}{l}\text { Aortic } \\
\text { valve } \\
\text { replacement }\end{array}$ & 3.54 \\
\hline 9 & $\mathrm{M}$ & 63 & $\begin{array}{l}\text { Unstable } \\
\text { angina }\end{array}$ & $\begin{array}{l}\text { Swab + } \\
\text { CT chest }\end{array}$ & 9 & CABG & 1.03 \\
\hline 10 & $\mathrm{M}$ & 71 & STEMI & Swab & 84 & CABG & 4.06 \\
\hline
\end{tabular}

Table 1. Demographics, cardiac diagnosis and surgery performed. Details of the COVID-19 screening. CABG: Coronary artery bypass grafting; DTA: descending thoracic aorta; STEMI: ST elevation myocardial infarction.

\begin{tabular}{|c|c|c|c|c|c|c|c|c|}
\hline Patient & $\begin{array}{l}\text { COVID } \\
\text { symptoms }\end{array}$ & $\begin{array}{l}\text { Lowest } \\
\text { Lympho- } \\
\text { cyte } \\
\text { count }\end{array}$ & $\begin{array}{l}\text { Highest } \\
\text { LDH } \\
\text { Value }\end{array}$ & $\begin{array}{l}\text { Highest } \\
\text { Ct value }\end{array}$ & $\begin{array}{l}\text { CT } \\
\text { changes } \\
\text { Suggested } \\
\text { of COVID }\end{array}$ & $\begin{array}{l}\text { Mechanical } \\
\text { ventila- } \\
\text { tion times } \\
\text { (hours) }\end{array}$ & $\begin{array}{l}\text { Length of } \\
\text { ITU } \\
\text { admission } \\
\text { (days) }\end{array}$ & $\begin{array}{l}\text { Lengtl } \\
\text { postop } \\
\text { ative s } \\
\text { (days) }\end{array}$ \\
\hline 1 & No & 0.5 & 350 & 37.74 & No & 8 & 3 & 14 \\
\hline
\end{tabular}




\begin{tabular}{|c|c|c|c|c|c|c|c|c|}
\hline Patient & $\begin{array}{l}\text { COVID } \\
\text { symptoms }\end{array}$ & $\begin{array}{l}\text { Lowest } \\
\text { Lympho- } \\
\text { cyte } \\
\text { count }\end{array}$ & $\begin{array}{l}\text { Highest } \\
\text { LDH } \\
\text { Value }\end{array}$ & $\begin{array}{l}\text { Highest } \\
\text { Ct value }\end{array}$ & $\begin{array}{l}\text { CT } \\
\text { changes } \\
\text { Suggested } \\
\text { of COVID }\end{array}$ & $\begin{array}{l}\text { Mechanical } \\
\text { ventila- } \\
\text { tion times } \\
\text { (hours) }\end{array}$ & $\begin{array}{l}\text { Length of } \\
\text { ITU } \\
\text { admission } \\
\text { (days) }\end{array}$ & $\begin{array}{l}\text { Lengt } \\
\text { postol } \\
\text { ative } \\
\text { (days) }\end{array}$ \\
\hline 2 & Dyspnoea & 1.0 & $\mathrm{~N} / \mathrm{A}$ & 34.15 & Yes & 6 & 3 & 5 \\
\hline 3 & No & 1.6 & 177 & 35.14 & No & 24 & 4 & 9 \\
\hline 4 & No & 0.6 & $\mathrm{~N} / \mathrm{A}$ & 37.24 & Yes & 12 & 4 & 48 \\
\hline 5 & No & 1.9 & 216 & 31.63 & No & 4 & 1 & 4 \\
\hline 6 & No & 1.8 & 162 & 0 & Yes & 4 & 1 & 6 \\
\hline 7 & No & 2.2 & 285 & 0 & Yes & 4 & 2 & 9 \\
\hline 8 & No & 0.4 & 249 & 0 & Yes & 5 & 7 & 12 \\
\hline 9 & No & 0.5 & $\mathrm{~N} / \mathrm{A}$ & 0 & Yes & 4 & 1 & 5 \\
\hline 10 & No & 1.1 & 160 & 28.08 & No & 4 & 3 & 7 \\
\hline
\end{tabular}

Table 2. Presence of COVID-19 symptoms and screening adjuncts: lymphocyte count and Lactate dehydrogenase $(\mathrm{LDH})$ values, non-contrasted chest computed tomography (CT). Postoperative outcomes: length of intensive care (ITU) stay. Ct: cycle threshold. N/A (Not-available) - haemolysed sample.

\section{REFERENCES}

1. Cai Y, Hao Z, Gao Y, Ping W et al. Coronavirus disease 2019 in the perioperative period of lung resection: a brief report from a single thoracic surgery department in Wuhan. J Thorac Oncol. 2020;15:1065-72/

2. Lei S, Jiang F, Su W, Chen $\mathrm{C}$ et al. Clinical characteristics and outcomes of patients undergoing surgeries during the incubation period of COVID-19 infection. EClinicalMedicine. 2020;21:100331.

3. Yates M, Balmforth D, Lopez-Marco A, Uppal R et al. Outcomes of patients diagnosed with COVID-19 in the early post-operative period following cardiac surgery. Interact CardioVasc Thorac J Published online first 2020.

4. Hussain A, Balmforth D, Yates M, Lopez-Marco A et al. The Pan London Emergency Cardiac Surgery Service: Coordinating a response to the COVID-19 Pandemic. J Card Surg 2020;1-7.

5. La Scola B, Le Bideau M, Andreani J, Hoang VT et al. Viral RNA load as determined by cell culture as a management tool for discharge of SARS-CoV-2 patients from infectious disease wards. Eur J clin Microbiol Infect Dis 2020. 39:1059-1061. 